\title{
É chegada \\ "a ocasião da negrada bumbar" \\ comemorações da Abolição, música e política na Primeira República*
}

\section{"É chegada a ocasião da negrada bumbar" \\ commemoration of the slavery Abolition, culture and politics in the Brazilian First Republic}

\author{
MARTHA ABREU \\ Professora Associada do Departamento de História da UFF \\ Doutora em História pela UNICAMP \\ UFF, Campus do Gragoatá, Programa de Pós-graduação em História, \\ Rua Prof. Marcos Waldemar de Freitas Reis, Bloco O, sala 505, \\ 24210-380, Niterói, $R J$ \\ martha.abreu@pq.cnpq.br \\ Carolina VIANNA DANTAS \\ Bolsista PRODOC/CAPES no Programa de Pós-graduação em História da UFF \\ Doutora em História pela UFF \\ UFF, Campus do Gragoatá, Programa de Pós-graduação em História, \\ Rua Prof. Marcos Waldemar de Freitas Reis, Bloco O, sala 505, \\ 24210-380, Niterói, RJ \\ carolinavdts@gmail.com
}

RESUMO Este artigo tem como objetivo problematizar a questão da participação política dos negros na Primeira República a partir das comemorações do $21^{\circ}$ aniversário da abolição realizadas na capital federal, em 1909. Personagens de destaque neste evento, o político Monteiro Lopes e o músico Eduardo das Neves são tomados como exemplos emblemáticos de formas de expressão e participação experimentadas naquele período.

* Artigo recebido em: 17/04/2011. Autor convidado. 
Palavras-chave comemorações, Abolição, música, política, Primeira República

ABSTRACT This article aims to discuss the issue of mobilization and political participation of black people in I republic from the celebrations of the 21 st anniversary of the abolition held in the federal capital in 1909. Celebrities featured in this event, the politician Monteiro Lopes and musician Eduardo das Neves are taken as significative examples of forms of expression and participation experienced in that period.

Keywords celebration, slavery abolition, music, Politics, Brazilian First Republic

O dia 13 de maio de 1909 foi mais um dia de festa para os habitantes capital da república. Como em outros anos, comemorava-se o aniversário da abolição. ${ }^{1}$ Esse ano, contudo, parecia especial, pois também se festejava a entrada na Câmara dos Deputados do primeiro político que assumia, em público, ser orgulhosamente "negro": Manoel da Motta Monteiro Lopes (PE, 1867- RJ, 1910). Por sua vez, Eduardo das Neves (RJ, 1874 - RJ, 1919), que se auto-proclamava o "Crioulo Dudu", também participou das comemorações com suas músicas e versos. ${ }^{2}$

Monteiro Lopes e seus companheiros organizaram atividades nas áreas centrais da cidade, conseguindo a colaboração de muitas pessoas, comerciantes e entidades. O ministro da Marinha disponibilizou bandas de música para o evento, assim como os Bombeiros e o Exército; a Light cedeu bondes gratuitamente e os edifícios públicos foram iluminados exclusivamente para a data. Os comandantes dos navios de guerra, um pouco antes da Revolta da Chibata (1910) leram aos seus subordinados (entre os quais, havia muitos negros) "patrióticas ordens, comemorando a lei que (...) igualou todos os brasileiros". Nos cinematógrafos do Centro e dos subúrbios foram exibidas fitas "de apoteose à grande data, apresentando diversos retratos de heróis abolicionistas". No parque da Praça da República festas escolares homenagearam a Lei Áurea. Em várias igrejas,

1 Sobre as variadas comemorações da abolição, ver: MORAES, Renata Figueiredo. Os maios de 1888: história e memória na escrita da História da Abolição, o caso de Osório Duque-Estrada. Niterói: UFF, 2007. (História, Dissertação de mestrado) e DAIBERT Jr., Robert. Isabel, a "redentora" dos escravos: uma história da Princesa entre olhares negros e brancos (1846-1988). Bauru/São Paulo: EDUSC, 2004.

2 Monteiro Lopes identificava-se publicamente com o termo "negro" e, em seus discursos, dirigia-se aos seus ouvintes com o mesmo termo, conferindo-lhe um sentido positivo e afirmativo. Eduardo das Neves em uma de suas canções definia-se, com orgulho, como o "Crioulo Dudu das Neves". NEVES, Eduardo das. O trovador da malandragem. Rio de Janeiro, Livraria Quaresma Editores, 1926, p.64. 
principalmente, naquelas que abrigavam irmandades negras, rezaram-se missas pelos abolicionistas mortos e "pelo feliz resultado" da eleição de Monteiro Lopes. Na Câmara aconteceu uma sessão solene e o orador oficial do evento proclamou em seu discurso "que a entrada de Monteiro Lopes para o parlamento brasileiro era uma afirmação de que o preto, através do desenvolvimento do Brasil, aparecia sempre como elemento de força e de civismo em todos os poderes da pátria". ${ }^{3}$

Esse tipo de celebração - acompanhada de bandas, iluminação e decoração nos prédios, discursos acalorados e missas - eram comuns nas festas públicas e cívicas realizadas na cidade. ${ }^{4} \mathrm{O}$ que talvez surpreenda os leitores de hoje é o fato de essas celebrações terem ocorrido em comemorações pelos 21 anos da abolição e pela posse de um deputado negro, nas quais também houve espaço para denúncias de discriminação racial e para a afirmação da importância dos negros na história, na cultura, na república e na nação.

Por muito tempo nos acostumamos a enxergar a Primeira República como um período negativo - e velho - no que diz respeito ao exercício da cidadania, seja em termos de participação política ou expressão cultural da população. Estamos habituados e condicionados a versões poderosas, produzidas posteriormente, que defendem o domínio quase absoluto de políticas voltadas para a europeização dos costumes e para a repressão aos movimentos políticos, sociais e culturais dos setores populares e negros. Entretanto, pesquisas e reflexões mais recentes têm ajudado a dar visibilidade à diversidade de experiências de expressão cultural e participação política, demonstrando que os velhos modelos interpretativos não são suficientes e não conseguem mais dar conta das histórias de muitos dos agentes sociais daquele tempo. ${ }^{5}$

Aquela festa do 13 maio de 1909 teve mesmo um caráter especial. Ainda sob a supervisão de Monteiro Lopes, organizou-se uma romaria ao túmulo de José do Patrocínio no Cemitério do Caju. A Gazeta de notícias registrou a presença de uma multidão composta trabalhadores, sindicatos, irmandades negras, abolicionistas e republicanos históricos, entre outros simpatizantes. Lá chegando, o sr. Israel dos Santos, segundo o jornal "o decano dos abolicionistas", deu a palavra a Monteiro Lopes. Em seguida, "fez-se um profundo silêncio entre os romeiros e o dr. Monteiro Lopes começou a falar".

\footnotetext{
Jornal do Brasil, 14/05/1909.

Ver OLIVEIRA, Lucia Lippi. As festas que a república manda guardar. Estudos Históricos, v.2, n.4, 1989. Segundo a autora, entre outras festas nacionais, o 13 de maio foi considerado como o dia da "fraternidade nacional" e era feriado em todo o país, conforme o disposto no Decreto n.155 B do Governo Provisório de 14 de janeiro de 1890 Ver também, BONAFE, Luigi. Como se faz um herói republicano: Joaquim Nabuco e a República. Niterói: UFF, 2008. (História, Tese de doutorado).

5 GOMES, Ângela de Castro Gomes; ABREU, Martha. A "nova velha" república: um pouco de história e historiografia. Niterói, Tempo, v.13, n.26, 2009.
} 
Diante do túmulo de José do Patrocínio, exaltou o "herói do 13 de maio" e jurou defender sua "raça fraca e oprimida diante dos insubmissos que ainda não compreenderam que a lei do 13 de maio de 1888 firmou a igualdade dos brasileiros". Destacou ainda, o fato ter enfrentado como adversário, nas eleições de 1909, o Conselheiro Andrade Figueiredo, o "maior escravagista, que nem ao menos, momentos antes da passagem da lei 13 de maio, se converteu ao credo abolicionista". E, assim, declarou "a suprema glória" que sentia de por "mais uma vez (...) ter dado combate ao último reduto do escravagismo". Interrompido diversas vezes por aplausos, terminou seu discurso defendendo a construção de uma estátua de bronze em homenagem a Patrocínio e dando vivas à república, que, segundo ele, buscou o seu próprio "nascimento no ocaso do sol de 13 de maio!".

Em seguida, ouviu-se o discurso de Lopes Trovão, abolicionista e líder histórico republicano. Em suas palavras, José do Patrocínio certamente estaria decepcionado com os rumos que a república havia tomado ao "perseguir o povo e confiscar os seus direitos". Aquela não seria a república defendida por eles em seus "comícios populares" durante a Campanha Republicana: "a república ainda não está feita", ratificou. Por isso, em tom, ao mesmo tempo, pessimista e combativo, lembrou ao

povo que não é somente a entrada do Dr. Monteiro Lopes na Câmara dos Deputados pelo voto unânime dos seus concidadãos ${ }^{6}(. .$.$) que traduz fielmente os$ princípios democráticos apregoados por mim e José do Patrocínio (...) muita coisa resta a fazer, porque a lei de 13 de maio igualou os direitos dos brasileiros, a república assegurou as garantias constitucionais, o que até hoje não se tem feito nem mesmo há esperanças de fazer. O que está aí não é república. ${ }^{7}$

De acordo com o jornal, Lopes Trovão foi "delirantemente aplaudido". 8

Depois foi a vez do professor Rego Medeiros, sobre o qual temos poucas informações. Apelando para o simbolismo abolicionista, levou consigo uma palma de samambaia e camélias brancas e lembrou que a eleição de Monteiro Lopes "era um dos maiores triunfos conquistados pela lei de13 de maio". Por isso, não se podia aceitar que, depois da abolição, a república viesse estabelecer distinção "de classe e de cores" e impedisse que Monteiro Lopes - "o tipo clássico do negro nacional" - entrasse no parlamento. Afinal, segundo Medeiros, todos os brasileiros teriam "sangue africano" nas veias e, por isso, louvava José do Patrocínio e sua "obra política", que teriam aberto o caminho para a entrada de um homem como Monteiro Lopes na Câmara dos Deputados. ${ }^{9}$

\footnotetext{
6 Note-se que essa afirmação de Lopes Trovão é outra importante pista sobre a possibilidade do eleitorado de Monteiro Lopes ser composto, em sua maioria, por negros.

7 Gazeta de Notícias, 14/05/1909.

8 Gazeta de Notícias, 14/05/1909.

9 Gazeta de Notícias, 14/05/1909.
} 
As comemorações prosseguiram com o discurso, do já referido, sr. Israel dos Santos, feito em nome das irmandades de São Benedito, Nossa Senhora do Rosário e Santa Ifigênia.

Como indicou Ângela de Castro Gomes, a abolição e a república tornaram realidade o princípio da equidade política no Brasil. E ainda que não tenham proporcionado conquistas amplas, a garantia formal da igualdade civil foi um marco importante no processo de conquista dos direitos de cidadania no Brasil. ${ }^{10}$ Se, em 1909, a restrição do voto aos alfabetizados, as fraudes nas eleições, as práticas políticas coronelísticas e oligárquicas eram uma realidade, as lutas em busca de ampliação dos espaços de expressão, afirmação e participação na esfera pública também se fizeram presentes e significativas. Partindo de um olhar que busca resgatar a imprevisibilidade da história, é possível identificar que para os artistas, intelectuais, políticos e trabalhadores negros citados aqui essa não era um batalha perdida, fadada ao fracasso. Havia expectativas quanto às possibilidades de inclusão e foi esse o caminho que buscaram trilhar nos palcos, na imprensa, nos comícios em praça pública, nas gravadoras de discos, nos clubes recreativos, nas associações e irmandades negras, nos terreiros, nas festas e folias, e no parlamento.

Entretanto, embora nosso foco esteja voltado, especificamente, para as trajetórias de dois homens negros, é relevante registrar a presença do republicano histórico Lopes Trovão na mesma comemoração pela abolição. A causa de uma república democrática, onde os direitos civis de fato tivessem valor e os direitos políticos e sociais fossem ampliados, era possivelmente uma bandeira mais ampla. Faziam parte de projetos e pretensões políticas de diversos sujeitos sociais.

Assim, paralelamente à festa organizada por Monteiro Lopes em 1909, a Liga de Educação Cívica da Cidade do Rio de Janeiro ${ }^{11}$ também promoveu alguns eventos em homenagem à abolição. A convite da Liga, o músico negro Eduardo das Neves apresentou-se no bairro do Méier, onde executou suas cançonetas e modinhas ao violão e ao piano. Pode dar o que pensar o fato de o músico negro apresentar-se em uma celebração pela abolição de um grupo preocupado com a educação cívica da cidade capital. O programa da apresentação também incluiu, como destacou a

10 Ver GOMES, Ângela de Castro. Venturas e desventuras de uma república de cidadãos. In: ABREU, Martha e SOIHET, Rachel. (orgs.) Ensino de História. Rio de Janeiro: Casa da Palavra, 2003.

11 Temos poucas informações sobre a atuação dessa Liga de Educação Cívica no Rio de Janeiro, mas há indícios de que fosse uma entidade civil de orientação republicana que buscava promover o sentimento patriótico e a educação cívica do povo. Há uma organização contemporânea a essa, com o mesmo nome e atuação semelhante, só que na Bahia. Podemos considerar que poderia haver uma afinidade de valores entre a Liga e Eduardo das Neves e, que, a escolha dele - referido pela Gazeta de Notícias na ocasião do evento como "o popular cantor de modinhas" - para se apresentar naquele 13 de maio não tenha sido aleatória. Ver Gazeta de Notícias, 13/05/1909. 
Gazeta de Notícias, a declamação da poesia Lucia, a escrava, de Castro Alves, o famoso poeta da liberdade. ${ }^{12}$

Conhecido como "crioulo Dudu", posto que ele próprio assim se chamava, Eduardo das Neves fazia presença. Já bastante conhecido, deve ter ajudado a atrair muita gente aos eventos cívicos e festivos no Méier. Possuía uma voz tão poderosa que havia sido contratado pela Casa Edison para as gravações de músicas populares, cançonetas e hinos patrióticos, num período em que a indústria fonográfica, tecnicamente, só conseguia gravar vozes especiais. ${ }^{13}$ Com tantos atributos vocais, deve ter sido impactante ouvi-lo declamando Castro Alves, poeta que combateu a escravidão e criou versos cheios de emoção, ótimos para serem declamados. A poesia Lúcia, a escrava foi escrita em 1868 e publicada em 1881, mas, em 1909, ainda era lembrada nos rituais republicanos de celebração de mais um ano da abolição. Intencionalmente, os sofrimentos da escravidão e os heróis da luta pela abolição eram trazidos à tona para marcar a luta pela igualdade numa república que havia perpetuado diversas formas de desigualdade e discriminação racial.

Na formosa estação da primavera

(...)

Eu e Lúcia, corríamos - crianças -

(...)

Ela era a cria mais formosa e meiga

Que jamais, na fazenda, vira o dia ...

Morena, esbelta, airosa... eu me lembrava

(...)

Ai! Pobre Lúcia... como tu sabias,

Festiva, encher de afagos a família,

Que te queria tanto e que te amava

Como se fosses filha e não cativa...

Tu eras a alegria da fazenda;

Tua senhora ria-se, contente

(...)

Mas um dia a miséria, a fome, o frio,

Foram pedir um pouso nos teus lares...

A mesa era pequena... Pobre Lúcia!

Foi preciso te ergueres do banquete

(...)

Pela última vez ela chorando

Veio sentar-se ao banco do terreiro...

Pobre criança! que conversas tristes

Tu conversaste então co'a natureza.

"Adeus! pra sempre, adeus, ó meus amigos,

(...)

12 Gazeta de Notícias, 13/05/1909.

13 FRANCESCHI, Humberto. A Casa Edison e seu tempo. Rio de Janeiro: Sarapuí, 2002. 
Perdoai-me que eu parto para sempre! Venderam para longe a pobre Lúcia!...".

(...)

Depois além, um grupo, informe e vago,

Que cavalgava o dorso da montanha,

la esconder-se, transmontando o topo. . .

Neste momento eu vi, longe... bem longe,

Ainda se agitar um lenço branco...

Era o lencinho trêmulo de Lúcia...

Epílogo

Muitos anos correram depois disto ...

Um dia nos sertões eu caminhava

Por uma estrada agreste e solitária,

Diante de mim ua mulher seguia,

- Co' o cântaro à cabeça - pés descalços,

Co'os ombros nus, mas pálidos e magros ...

Ela cantava, com uma voz extinta,

Uma cantiga triste e compassada ...

E eu que a escutava procurava, embalde,

Uma lembrança juvenil e alegre

Do tempo em que aprendera aqueles versos...

De repente, lembrei-me. . . "Lúcia! Lúcia!"

... A mulher se voltou ... fitou-me pasma,

Soltou um grito. . . e, rindo e soluçando,

Quis para mim lançar-se, abrindo os braços.

... Mas súbito estacou ... Nuvem de sangue

Corou-lhe o rosto pálido e sombrio ...

Cobriu co'a mão crispada a face rubra

Como escondendo uma vergonha eterna ...

Depois, soltando um grito, ela sumiu-se

Entre as sombras da mata ... a pobre Lúcia. ${ }^{14}$

Com tintas românticas muito fortes, a poesia mostra um dos aspectos mais dramáticos do cativeiro. Lúcia, a escrava sestrosa de Castro Alves, passou pela dura experiência de ser vendida para longe, de não ser livre para viver o amor e de não ser dona do seu próprio destino. Recitar o drama romântico de Lúcia no dia da festa nacional pela abolição poderia significar, naquele momento, o compartilhamento de um passado comum, tanto em função do martírio da escravidão, quanto em torno da atualização do marco da conquista da liberdade naquele momento, inclusive no aspecto das escolhas amorosas. A presença de Eduardo das Neves como intérprete era oportuna. Dudu, além dos dotes artísticos, era especialista em canções que falavam de amor; tornou-se conhecido pela divulgação de irreverentes versos que impressionavam positivamente moças de todas as

14 ALVES, Castro. Os escravos. Porto Alegre: L\&MP, 1997. 
cores e origens sociais. ${ }^{15} \mathrm{O}$ exercício da liberdade também se relacionava com as livres escolhas amorosas.

Não temos como saber se Monteiro Lopes e Dudu mantinham laços de amizade para além da participação, se bem que em locais diferentes, das festividades pelo $21^{\circ}$ ano da abolição. Eram, provavelmente, representantes das diferenças sociais e intelectuais que estabeleciam clivagens entre a própria população negra. Mas, assim como Monteiro Lopes, Eduardo das Neves tinha sido abolicionista, era republicano e não queria esquecer as conquistas, mesmo que ainda pequenas, da abolição.

Tais atos públicos como os que Monteiro Lopes e Dudu protagonizaram - promovidos em sua maioria por descendentes de africanos 21 anos depois da abolição - tinham um sentido político estratégico. Seguramente, uma das intenções (ou desejos) de Monteiro Lopes e Eduardo das Neves era questionar as desigualdades raciais e afirmar publicamente (e musicalmente no caso de Dudu) a igualdade de direitos estabelecida com a abolição e a república. Igualdade formal que deveria ser transformada em realidade.

Essas comemorações também evidenciam que o passado em comum de lutas pela liberdade durante a campanha abolicionista era um elemento fundamental de uma cultura política que ganhava as ruas no início do século XX. Afinal, um dos principais desdobramentos da campanha abolicionista foi a entrada na cena política de escravos, libertos e homens livres pobres, ocupando as ruas e os espaços públicos das cidades. ${ }^{16} \mathrm{E}$, se considerarmos que registrar o passado em festas, músicas, homenagens e em estátuas é estabelecer lugares de memória e avaliar as conquistas, Monteiro Lopes e Eduardo das Neves tinham muito em comum. Ambos se dedicaram a dar visibilidade aos negros na esfera pública, no âmbito da cultura e da política. Ironicamente, ambos foram esquecidos pelos historiadores da política e da música popular no Brasil.

Em diálogo com intelectuais e políticos, os descendentes de africanos estavam nas ruas - especialmente nas da capital da república - nas folias carnavalescas e nas festas populares, como as da Penha; agiam também contra o aumento de preços e a carestia, os baixos salários, as extenuantes jornadas de trabalho, os patrões, as reformas urbanas e sanitárias, e contra o que, em geral, consideraram como arbitrariedades do governo e dos patrões; lutavam por igualdade de tratamento, espaços de atuação, visibilidade, reconhecimento e autonomia. ${ }^{17}$ Portanto, podemos afirmar que na Primeira República, para além da repressão policial e dos arranjos oli-

15 Ver ABREU, Martha. "O Crioulo Dudu": participação política e identidade negra nas histórias de um músico cantor 1890-1920. Topoi, v.11, n.20, 2010.

16 MACHADO, Maria Helena P. T.. De rebeldes a fura-greves. In: GOMES, Flávio e CUNHA, Olívia M. G. da. (orgs.) Quase-cidadão. Rio de Janeiro: Editora. FGV, 2007, p.249.

17 Ver, por exemplo: CRUZ, Maria Cecília Velasco. Tradições negras na formação de um sindicato. Afro-Ásia, n.24, 2000; MATTOS, Marcelo Badaró. Escravizados e livres. Rio de Janeiro: Bom Texto, 2009. 
gárquicos, os negros criaram espaços capazes de oferecer possibilidades de expressão e de participação política. Compreender o que significavam esses espaços, entretanto, exige o alargamento do conceito de participação política, estendendo sua definição às atitudes, comportamentos e estratégias para além exercício do voto e dos resultados das eleições. Lutar por essas questões significava reafirmar direitos e interesses - redefinidos depois de 1888 e 1889 -, inclusive, em termos étnico-raciais, culturais e coletivos, como apontou Flávio Gomes. ${ }^{18}$

Nosso objetivo neste artigo é registrar os esforços de indivíduos e grupos negros em negociar as possibilidades e os limites de sua cidadania. Em meio à diversidade da experiência de descendentes de africanos no período, centraremos a atenção em alguns aspectos das trajetórias de Monteiro Lopes e Eduardo das Neves, que nos permitirão pensar em outras possibilidades de lutas políticas e culturais no pós-abolição. ${ }^{19}$

O primeiro, advogado e político negro, protagonizou campanhas eleitorais na capital da república; Das Neves, através de sua música, reafirmou a presença dos negros na jovem república: discutia as relações raciais e não parecia querer esquecer o 13 de maio de 1888. Inclusive, Dudu gravou pela Casa Edison/Odeon, por volta de 1909, canção "Canoa Virada", um hino à liberdade sob a forma de lundu, que discutiremos mais adiante.

\section{Do parlamento à música, outras formas de fazer política na Pri- meira República}

Monteiro Lopes se definia politicamente como republicano, socialista não-revolucionário, defensor dos trabalhadores e um crítico das políticas estaduais. ${ }^{20}$ Nasceu livre no mês dezembro de 1867, em Recife, Pernambuco. Segundo a Gazeta de notícias, ainda que filho de africanos e de origem pobre, conseguiu fazer seus primeiros estudos no Ginásio de Pernambuco, de onde saiu em $1883 \mathrm{com}$ o diploma de bacharel em humanidades. No mesmo ano, matriculou-se na Faculdade de Direito do Recife, formando-se em 1889. Em 1894, chegou à capital federal com o objetivo de ali advogar. Sabemos ainda que atuou ativamente no movimento abolicionista e na campanha republicana.

18 Ver GOMES, Flávio. Negros e política (1888-1937). Rio de Janeiro, Jorge Zahar Editor, 1995; GOMES, Flávio. Experiências atlânticas. Passo Fundo: UPF, 2003.

19 Sobre as especificidades do período pós-abolição no Brasil, ver MATTOS, Hebe e RIOS, Ana Lugão. Memórias do cativeiro: família, trabalho e cidadania no pós-abolição. Rio de Janeiro: Civilização Brasileira, 2005.

20 Ver, respectivamente: BELLO, José Maria. Memórias. Rio de Janeiro: José Olympio, 1958, p.64; ALENCAR, Edigar de. O carnaval carioca através da música. Rio de Janeiro: Livraria Freitas Bastos, 1965, p.71; DEODATO, Alberto. Políticos e outros bichos domésticos: crônicas. Belo Horizonte: Editora Itatiaia, 1962, p.221; EDMUNDO, Luiz. O Rio de Janeiro do meu tempo. Rio de Janeiro: Xenon, 1987, p.197; FRANCO, Afonso Arinos de Mello. Um estadista da república. Rio de Janeiro: José Olympio, 1955, p.1284; MARTINEZ, Sebastião. Pimenta, amor e chibata. Rio de Janeiro: H. Antunes, 1977, p.25; Anais da Câmara dos Deputados, 13/09/1910 e FRANCO, Afonso Arinos de Melo. Um estadista da república, p.625 
Monteiro Lopes vestia-se de maneira formal e sóbria: de casaca em tecido pesado e de cor escura, projetando uma aparência de seriedade e altivez. Residia no subúrbio, perto da Estação do Rocha-localidade próxima à área portuária da cidade - e mantinha um escritório na Praça Tiradentes. ${ }^{21}$

Monteiro Lopes também se associou a algumas organizações. São os chamados lugares de sociabilidade, isto é, espaços de fermentação intelectual e política e de relações afetivas, "um ponto de encontro de itinerários individuais"22 em torno dos quais debateu questões e viveu experiências comuns. Participava das atividades da Sociedade União dos Homens de Cor do Rio de Janeiro, era membro ativo da Irmandade de São Benedito e Nossa Senhora do Rosário. Também manteve contado com associações negras de fora do Rio de Janeiro, como a Federação Paulista dos Homens de Cor, o Colégio São Benedito e com lideranças negras e operárias, como Rodolpho Xavier, de Pelotas, e Benedito Florêncio, de Campinas. Essa rede de sociabilidades indica que Monteiro Lopes transitava no meio operário e associativista negro e nos meios intelectuais e políticos, exercendo uma dupla militância.

A maioria as fontes menciona que Monteiro Lopes era reconhecido como uma liderança pelo operariado das fábricas e por "operários de cor das oficinas municipais e federais". ${ }^{23} \mathrm{~A}$ partir das entidades que participaram da mobilização em prol da sua posse, em 1909, e das homenagens prestadas na ocasião do seu falecimento, em 1910, é possível identificar os grupos com os quais se relacionava mais diretamente: Sociedade de resistência dos trabalhadores em trapiches e café, Sociedade de resistência dos trabalhadores dos trapiches e carvão; militares de baixa patente e alferes; operários do Arsenal da Marinha; mestres da locomoção; operários da Fábrica de Cartuchos de Realengo; bagaceiros da Estrada de Ferro Central do Brasil; operários do Engenho de Dentro; operários da Imprensa Nacional; trabalhadores do Serviço de Prevenção à Febre Amarela; trabaIhadores das capatazias da Alfândega e "associações onde o elemento preto superabunda". ${ }^{24}$ Essas pistas nos indicam que é provável que muitos trabalhadores identificaram-se com Monteiro Lopes em função de afinidades étnico-raciais, até porque muitos dessas ocupações e associações contavam com uma maioria de trabalhadores negros, muitos descendentes de escravos.

Mas, o fato é que Monteiro Lopes conseguiu conquistar reconhecimento público na capital da república. Depois de exercer a advocacia por cerca

21 Também sabemos que Monteiro Lopes publicou o folhetim Os miseráveis do Recife, no jornal recifense Eco do Povo, em 1887 e o romance-novela Drama de sangue, em 1890, em fascículos. Entretanto, ainda não localizamos tais obras.

22 SIRINELLI, Jean-François. Os intelectuais. In: René Remond. (org). Por uma história política. Rio de Janeiro: FGV, 1996, p.46

23 LACERDA, Maurício de. Evolução legislativa do direito social brasileiro. Rio de Janeiro: Nova Fronteira, 1980, p.85.

24 A tribuna, 04/05/1909. 
de 10 anos, em 1903, foi eleito e reconhecido como membro do Conselho Municipal do Distrito Federal. Ao término do seu primeiro mandato (19031904) candidatou-se novamente ao cargo e, embora tenha conseguido uma expressiva votação, como informou a Gazeta de notícias, não foi reconhecido nem diplomado. Acabou degolado da legislatura seguinte do Conselho Municipal. ${ }^{25}$

Em 1905, Monteiro Lopes viveu episódio semelhante. Ao pleitear uma cadeira de deputado federal pelo então Distrito Federal - como de costume, sem se associar a partidos políticos - foi eleito, mas não diplomado. O próprio admitiu em uma entrevista ao jornal O commercio, de Bagé, que nessas duas ocasiões, ao ser eleito e não reconhecido, foi "esbulhado" em seus direitos. ${ }^{26}$

Ao ter sua entrada sistematicamente barrada em instituições como o Conselho Municipal e a Câmara dos Deputados, Monteiro Lopes mudou de estratégia: em 1909 apresentou-se novamente como candidato a deputado federal pelo $1^{\circ}$ distrito da capital federal, agora vinculado ao Partido Republicano Democrata. Segundo um dos seus dirigentes, o partido seria uma organização aberta a diversas tendências políticas e a livres pensadores, tendo como peças centrais do seu programa a ampliação da instrução pública e o sufrágio popular. ${ }^{27}$

A luta pela sua posse não foi fácil. Em fevereiro de 1909, logo após ser eleito pelo $1^{\circ}$ distrito da capital para o cargo de deputado federal, surgiram, na imprensa, rumores de que Monteiro Lopes não seria empossado em função de sua cor. O próprio, em entrevista ao jornal O commercio, de Campinas, apontou o Barão do Rio Branco como um dos "primeiros perseguidores" a sua diplomação. No dia 6 de fevereiro, por exemplo, a capa do periódico O malho trouxe um desenho de Monteiro Lopes posicionado entre Rio Branco e Afonso Pena. O título era Coisas pretas. Abaixo da charge havia o seguinte diálogo:

Pena - Vejam só isto! Até um preto, retinto como carvão, já é eleito deputado! Aí está o resultado do povo meter-se em política: qualquer borra-botas vale tanto como um titular...Não admito isso! (...)

Barão - Realmente, um pretalhão daquele eleito deputado, é uma espécie de eclipse na 'República dos Conselheiros'... é tudo quanto pode haver de mais democrático... de mais feniano...e até de mais tenente do diabo! Fica mesmo uma República Carnavalesca.

Pena - E eu dançando de velho no meio dela ... Pois sim! Vou por o intruso no meio da rua! Leve tudo o diabo, mas não consinto preto no rebanho! Quem faz a política é o pastor. E o pastor sou eu! ${ }^{28}$

\footnotetext{
25 Ver Gazeta de notícias, 13/12/1910 e 15/12/1910 e Fon fon. 12/04/1905.

26 A opinião pública, 31/01/1909.

27 Ver, A tribuna, 05/01/1909; A tribuna, 16/01/1909; Careta, 30/01/1909;

28 O malho, 06/02/1909.
} 
Diante dos rumores, Monteiro Lopes fez uma grande reunião com "homens de cor" no Centro Internacional Operário da capital, em 15 de fevereiro, para tratar de sua possível exclusão da Câmara. Entre outras coisas, deliberaram pedir apoio às corporações, aos sindicatos, aos jornais e às organizações compostas por "homens de cor" na cidade do Rio e em todo o país; fazer uma manifestação pública e solene à imprensa livre e independente, que, junto com o povo, "tem combatido o atentado que maus brasileiros projetam, como seja, excluir da representação nacional o Dr. Monteiro Lopes, julgando incompatível sua cor para fazer parte da Câmara dos Deputados, apesar de legalmente eleito"; convocar "um grande comício popular, onde será, dentro da ordem e da lei, lida uma enérgica mensagem contra o odioso sistema que se pretende implantar no regime republicano, fazendo-se distinção de raças e de castas, criando-se privilégios de cor, cindindo-se estupidamente a família brasileira". O Centro Internacional Operário também providenciou o encaminhamento de uma ação judicial em defesa do deputado eleito. ${ }^{29}$ Com uma saudação - "Viva a República sem o preconceito de cor!" -, todos se dispersaram na "melhor ordem", de acordo com a ata assinada pela "Comissão permanente contra a exclusão de Monteiro Lopes" publicada nos jornais. ${ }^{30}$

Por um lado, esses trabalhadores identificados como "homens de cor"31 reconheciam e afirmavam publicamente a existência de barreiras raciais naquela sociedade, por outro, não abriram mão do princípio formal inclusivo a partir do qual a república, como regime de governo é regida, tornando-o bandeira de luta. Desejam fazer cumprir o artigo 72 da Constituição de 1891, que garantia a igualdade de todos perante a lei. Havia, portanto, outros projetos de república. Se aquela não era a república dos sonhos, ${ }^{32}$ não desistiram de torná-la realidade, ainda que dentro da ordem e a despeito dos tantos obstáculos existentes.

Após a reunião no Centro Internacional Operário, a repercussão foi grande em vários jornais do país, ${ }^{33}$ tendo início uma importante mobilização de entidades formadas por negros nas cidades do Rio de Janeiro, Campinas e arredores, em cidades do Rio Grande do Sul, da Bahia, Ceará e Pernambuco. ${ }^{34}$ Esse movimento resultou em vários telegramas enviados e publicados nos jornais, em reuniões e em cartas enviadas a políticos de

29 Ver XAVIER, Rodolpho. Uma oportunidade. In: A alvorada, 06/03/1932; XAVIER, Rodolpho. Revivendo o passado. In: A alvorada, 07.06.1952.

30 Correio da manhã, 16/02/1909. Ver também A opinião pública durante o mês de fevereiro.

31 Termo utilizado recorrentemente pela imprensa da época para nomear os indivíduos e grupos mobilizados em prol da eleições de Monteiro Lopes. Ver, por exemplo, A confederação dos Homens de cor. In: A tribuna, 04/05/1909.

32 A autoria da frase "Essa não é a República dos meus sonhos" é atribuída ao republicano histórico e signatário do Manifesto Republicano (1870) Saldanha Marinho (PE, 1816 - RJ, 1895). Tal frase tornou-se uma espécie de emblema do lamento de uma geração de intelectuais decepcionados com os rumos tomados pela república após a proclamação, em 1889.

33 A opinião pública, 07/04/1909.

34 Correio da manhã, 18/02/1909; 19/02/1909; 07/03/1909 e 04/05/1909 
prestígio regional e nacional, como Rui Barbosa, Pinheiro Machado e Venceslau Brás. O debate sobre a questão racial e sobre o lugar dos "homens de cor" na política e na nação ganhou as páginas dos principais periódicos brasileiros, da grande imprensa à imprensa alternativa.

Um jornalista do Correio da manhã avaliou a situação, afirmando que a aglutinação de "todas as classes de homens de cor" em torno da candidatura de Monteiro Lopes só foi possível porque esse era um movimento que já vinha ocorrendo há muito tempo. Afinal, abolição e a república haveriam aberto portas para os negros, que a partir de então deixaram de ser coisa para transformarem-se em cidadãos. Prova disso seriam representantes ilustres dos "homens de cor" presentes naquele momento no campo das ciências, das letras, das artes, do magistério, da medicina, da advocacia, da literatura e do comércio. Faltava apenas um lugar a ser desbravado: o congresso nacional. Por isso é que, em 1909, de norte a sul da república havia ligas, clubes e associações onde indivíduos negros se reuniam regularmente, convergindo "esforços para a formação de um forte partido político, chefiado pelo deputado negro, e por ele terçando as armas". ${ }^{35}$

Esses textos - e os vários outros - sobre a eleição de Monteiro Lopes publicados na imprensa são bons exemplos do quanto alguns grupos compostos por negros naquele momento estavam empenhados em mostrar que o debate sobre a representação política formal também lhes dizia respeito. A mobilização alcançada também evidencia que os "homens de cor" (ou ao menos parte deles, como intelectuais e trabalhadores ligados ao "meio negro") sabiam o quanto as demonstrações públicas de união e força eram importantes ${ }^{36}$ para a conquista de espaços de visibilidade, expressão e participação.

A posse de Monteiro Lopes foi comemorada, não por acaso, junto com o $21^{\circ}$ aniversário da abolição. O deputado queria ser visto e guardado para a posteridade como um negro que conquistou a duras penas a educação formal em instituições renomadas e serviu à pátria, participando do movimento abolicionista, da campanha republicana e das lutas por direitos civis e sociais, entrando orgulhosamente pela porta da frente no parlamento brasileiro.

Suas propostas e projetos apresentados na Câmara priorizaram a luta por direitos trabalhistas. Adepto do sindicalismo reformista, suas principais intervenções relacionavam-se aos problemas derivados da exploração do operariado; à falta de legislação sobre o trabalho no Brasil; à necessidade de criação de um ministério do trabalho; ao absurdo da exploração do trabalho de menores e crianças e à situação precária em que ficavam as famílias

35 Correio da manhã, 04/03/1909.

36 NASCIMENTO, Álvaro Pereira do. Um reduto negro: cor e cidadania na Armada. In: GOMES, Flávio e CUNHA, Olívia M. G. da. Quase-cidadão, p.308. 
de operários acidentados ou mortos; à concessão de aposentadorias e aumento de vencimentos para alguns trabalhadores e categorias profissionais. Era preciso, argumentava Monteiro Lopes, que fossem assegurados aos operários os direitos garantidos na Constituição Republicana, pois para ele era óbvio que a república não deveria ser por princípio "o regime da impunidade, da injustiça, dos privilégios e da desigualdade". ${ }^{37}$ Quase todos os seus projetos foram recusados.

Sobre a atuação de Monteiro Lopes na Câmara cabe ainda chamar a atenção para dois aspectos. O primeiro deles é a ausência de menções ao preconceito de $\operatorname{cor}^{38}$ e às barreiras raciais existentes naquela sociedade, com as quais ele próprio de deparou. Esse era um tema delicado e Monteiro Lopes tinha dificuldade em fazer valer sua palavra no plenário. Afinal, era a palavra de um negro que não projetou sobre a população negra uma imagem passiva ou inferiorizada e, que, por diversas vezes, foi acusado por seus adversários de disseminar o preconceito de cor no Brasil ao racializar os debates e embates em torno de sua posse. Além disso, não podemos esquecer que o discurso abertamente ancorado na raça lembrava a explosão de ódios raciais e os linchamentos de negros que vinham ocorrendo no sul dos Estados Unidos, desde o final do século XIX. Os intelectuais brasileiros conheciam essa realidade e a temiam. ${ }^{39}$ Monteiro Lopes não deveria pensar muito diferente, pois se preocupava em manter seu projeto assimilacionista dentro dos limites da legalidade. E pelo menos em uma ocasião, ao ser acusado na imprensa de introduzir ódios raciais no Brasil e/ou perceber a iminência da eclosão conflitos raciais em torno de si, cancelou os comícios em prol de sua diplomação que seriam realizados na capital da república e em Pelotas. Talvez, como homem letrado e homem da lei que era, tivesse algum receio do clamor das ruas.

Mas, se Monteiro Lopes não abordou a questão racial em seus discursos na Câmara, é possível acompanhar suas ideias sobre esse tema através de jornais, nos quais foram transcritos alguns de seus discursos feitos em eventos públicos e aos quais concedeu entrevistas. Um desses pronunciamentos públicos foi feito em Porto Alegre, na ocasião em que foi agradecer às manifestações de apoio de lá recebidas. Ao chegar na cidade no dia 21 de janeiro de 1910 foi "insistentemente aclamado" e fez um discurso no qual declarou ser "homem de trabalho, acostumado às lutas políticas, confiando sempre na vitória dos princípios republicanos" e, por isso mesmo, sempre teria acreditado que a "Câmara Republicana" jamais

37 Anais da Câmara dos Deputados, 1909

38 Termo recorrentemente utilizado pela imprensa na época para referir-se às práticas de discriminação racial contra negros, então existentes.

39 Ver, por exemplo, WASHINGTON, Booker. In: Almanaque Brasileiro Garnier, 1905; BILAC, Olavo. Crônica. In: Gazeta de notícias, 21/01/1906; BILAC, Olavo. Crônica. In: Correio paulistano, 23/06/1908. Apud: DIMAS, Antonio. Bilac, o jornalista. São Paulo, Imprensa Oficial/EDUSP/Editora UNICAMP, v.1, p.773-774; MORAES, Evaristo de. A Cor... política Oposição ao preto! In: Correio da manhã, 14/02/1909; A tribuna, 17/02/1909, entre outros. 
desrespeitaria "o mandato que the fora outorgado por um eleitorado livre e independente". Repetiu que havia sido eleito pelo voto daqueles que reconheceram seus méritos e os serviços que prestou à república. Foi veemente em dizer que não estava subordinado aos jogos políticos oligárquicos, mas a sua consciência.

Disse ainda, à pequena multidão, que acreditava "que o negro não deve envergonhar-se de ser negro e que o mulato deve estar sempre ao lado deste". Afinal, argumentou, no Brasil não deveria haver "preconceito de cor" pelo motivo de haver aqui uma "vasta mestiçagem". A principal estratégia dos negros contra a discriminação da qual eram alvos deveria ser "instruir e educar seus filhos porque necessariamente eles ocuparão as mais altas posições no Brasil, pois a Constituição em seu artigo 72, mantém a igualdade perante a lei". Assim, defendendo o cumprimento das prerrogativas constitucionais, o deputado entendia que nas escolas públicas os professores não poderiam excluir "o menino pela cor". A função do professor deveria ser educar e não estabelecer "no ânimo da criança brasileira o ódio e a distinção de raças". Chegou a dizer que um professor que agisse assim deveria ser considerado um "criminoso", pois autor de um "atentado maldito", de um "abuso". Atitudes desse tipo, defendeu, deveriam ser censuradas pela imprensa, pelo parlamento e em comícios populares. Afinal, disse ele, quando a pátria estava em perigo, ninguém se importava com a cor do soldado; o que se esperava dele eram bravura e altivez na defesa da integridade do país. Então, perguntou Monteiro Lopes aos ouvintes: "Como, pois, sermos oprimidos e envergonharmo-nos de nós mesmos?" Mais uma vez, pediu que o Rio Grande do Sul abrisse suas escolas "aos negros". Antes de ser interrompido por ovações e aplausos, ratificou: "Negros, instrui-vos, glorificai a república e amai a liberdade!" Segundo os jornais, uma prolongada salva de palmas soou. ${ }^{40}$

Monteiro Lopes faleceu sem completar seu mandato no dia 13 de dezembro de 1910, na cidade do Rio de Janeiro. Sua última intervenção no plenário da Câmara foi no dia 25 de outubro de 1910: ao lado da maioria dos deputados, votou a favor da anistia dos marinheiros envolvidos na Revolta da Chibata.

O número de indivíduos, grupos e associações envolvidos em sua campanha e posse, evidentemente, extrapolou o quantitativo de seus eleitores e os limites geográficos de sua atuação política mais direta. É digno de nota que Monteiro Lopes foi eleito pelo primeiro distrito da capital federal com 2.164 votos, vindos, em geral, do funcionalismo público do baixo escalão

40 Ver Correio do povo, 22/01/1910. A opinião pública, 25/01/1910. Vale ressaltar que a menção positiva e pública de Monteiro Lopes ao termo "negro" e à necessidade dos "mulatos" estarem ao lado dos negros é uma pista da existência de uma identidade negra compartilhada naquele momento. 
e do operariado, segundo os jornais..$^{41}$ Não podemos afirmar que seu eleitorado fosse exclusivamente composto por negros, mas o fato de Monteiro Lopes ser denominado pela imprensa como líder dos trabalhadores onde o "elemento preto superabunda" e, por ter conseguido a mobilização de entidades compostas por negros, são pistas importantes sobre seu eleitorado. E, ainda que seja difícil quantificar e dimensionar um perfil político ou sócio-econômico das "multidões" que o acompanharam pelo país afora, não podemos descartá-las como evidências de que uma parte importante da população negra estava distante do conformismo e da despolitização que frequentemente se Ihes imputa a historiografia.

Os significados da eleição de Monteiro Lopes indicam, sem dúvida, o quanto leituras compartilhadas do passado, no caso da abolição e República, poderiam canalizar as lutas pelo acesso à educação, para a conquista de direitos e espaços de participação política. Ao levar às ruas e às praças públicas, à imprensa e aos sindicatos, às associações e ao parlamento a questão racial, tornou pública a demanda e os projetos de intervenção daqueles que estavam distantes do sistema político-partidário formal controlado pelas oligarquias estaduais. E, ainda que o voto não fosse um direito amplo naquela sociedade, havia setores da população negra que valorizavam a esfera da representação política formal, o Parlamento e seus desdobramentos como um importante espaço de participação política, evidenciando que existiam expectativas em relação às eleições na Primeira República.

Paralelamente, e em estreito diálogo com os processos eleitorais que mobilizavam a população, grupos formados por negros e populares marcaram o seu lugar no espaço público e na política da capital da república através das atividades musicais e festivas. ${ }^{42} \mathrm{~A}$ trajetória do músico cantor Eduardo das Neves, especialmente a escolha de seu repertório, nos auxilia a pensar a questão.

Eduardo Sebastião das Neves teria nascido na cidade do Rio de Janeiro, bairro de São Cristóvão, em 1874, e falecido nesta mesma cidade, em 1919, com apenas 45 anos. Poucas informações de seu passado revelam sua condição de homem pobre e negro no século XIX. Sabemos por registros de jornais, literatos, folcloristas e memorialistas que Das Neves foi um famoso cantor na sua própria época. Tocador de choros ao violão, autor e divulgador de lundus, modinhas e hinos patriotas, morreu pobre um pouco depois de o samba, gênero que também gravou, estourar como novo estilo de dança e música. Na sua carreira artística, apresentou-se em palcos dos

41 Do $1^{\circ}$ distrito da capital federal, Irineu Machado foi o mais votado, com 4.994 votos. O quinto e último candidato obteve 1.766, o que nos dá a dimensão da quantidade reduzida de eleitores na capital, que na época contava com cerca de 1 milhão de habitantes. Correio da manhã, 08/03/1909.

42 Nessa perspectiva, ver CUNHA, Maria Clementina Pereira da. Ecos da folia. São Paulo: Companhia das Letras, 2001 e ALBUQUERQUE, Wlamyra. O jogo da dissimulação. São Paulo: Companhia das Letras, 2009. 
cine-teatros, dos cafés-cantantes e teatros, onde se apresentava como "crioulo Dudu" e exibia, com elegância, um smoking azul e chapéu alto.

Envolveu-se também com as atividades de palhaço, tendo trabalhado nos melhores circos da capital e percorrido vários Estados do Brasil. Chegou a ser empresário do circo Brasil, que, em 1910, realizou uma grande apresentação na rua de Santana, na Praça Onze, coração musical da cidade. Os circos entre o final do século XIX e início do XX ocupavam um importante espaço do entretenimento popular e faziam circular por todo o Brasil as novidades musicais, teatrais e políticas. ${ }^{43}$

Através da popular editora Quaresma, Eduardo das Neves publicou expressivos livros, que reuniam canções de sua autoria e outras trazidas de várias partes do Brasil e do passado escravista: O cantor de modinhas brasileiras (com prefácio de Catulo da Paixão Cearense, 1895, 9a edição), Mistérios do violão (1905), Trovador da malandragem (1926, $2^{\mathrm{a}}$ edição, com canções registradas entre 1889 e 1902) e Trovador popular moderno (1925, $16^{a}$ edição, reunindo modinhas brasileiras de seu repertório e do também muito famoso cantor Baiano). A editora Quaresma era especializada em livros com temas atraentes e de grande circulação. ${ }^{44}$ Em 1902, Dudu foi contratado como cantor pela Casa Edison, a representante da gravadora de discos Odeon no Brasil. ${ }^{45}$ Dudu foi um dos quatro primeiros músicos contratados pela gravadora e o primeiro que se auto-intitulava "crioulo".

A partir da análise de sua produção musical e poética, publicada e gravada, tem sido possível perceber também o quanto, entre o final do século XIX e o início do XX, as questões da política e da nação eram discutidas e circulavam em diferentes ambientes frequentados por Dudu. Embora predominassem entre suas canções temas ligados às relações amorosas, as canções de cunho político e que celebravam a nação eram expressivas. E não só em canções feitas para a pilhéria e o tribofe da política e do cotidiano, como as que abordavam as fraudes nas eleições e as bajulações aos políticos. Destacam-se também de seu repertório as que valorizavam lideranças republicanas, criticavam os problemas da cidade, festejavam a pátria e seus heróis, como Santos Dumont, e integravam as diferentes regiões do Brasil através do folclore musical. O "crioulo Dudu das Neves" incluía-se com suas canções na pátria brasileira e republicana.

Sem dúvida é difícil entender completamente a lógica da escolha de seus heróis e temas, pois temos que considerar muitas variáveis, como a interferência dos editores, as chances de fazer sucesso de público e as próprias convicções do cantor/compositor. Se líderes do panteão republi-

43 Sobre os circos, ver DUARTE, Regina H. Noites circenses - espetáculos de circo e teatro em Minas Gerais no século XIX. Campinas: Editora Unicamp, 1995.

44 Ver, EL FAR, Alessandra. Páginas de sensação. São Paulo: Companhia das Letras, 2004.

45 FRANCESCHI, Humberto. A Casa Edison. 
cano estão presentes, como o Marechal Deodoro, assim como militares oriundos da Guerra do Paraguai, como o Marechal Bittencourt, a presença de uma homenagem a Campos Sales, reconhecido inimigo dos jacobinos, pode demonstrar que suas canções, como ele mesmo afirmava, obedeciam também às circunstâncias do momento. Dudu demonstrava ser um ótimo cronista da cidade.

Da mesma forma que políticos, intelectuais e representantes de associações de classe, Eduardo das Neves não se mostrava distante ou indiferente de acontecimentos que mobilizavam ações cívicas, patrióticas e republicanas. Pelo contrário, a música de Dudu - e sua repercussão - revela o quanto a população, e representantes da população negra, envolvia-se nas construções simbólicas e festivas da nova República e da própria nação. Apesar de criticado por poetas eruditos, que desqualificavam seus versos, o músico cantor não estava sozinho. Além de atores como Francisco Correa Vasques ${ }^{46}$ do editor Quaresma e de Fred Figner, empresário da Casa Edison, os folcloristas do final do século XIX e início do XX registraram um número significativo de músicos e cantadores, que, representantes de uma prática cultural disseminada por todos os cantos do país, discutiam o cotidiano, a nação e a política através de versos e músicas. A cultura das ruas invadia os teatros ${ }^{47}$ os cafés concertos, as casas dançantes, a indústria fonográfica e as editoras.

Mas os lundus e canções protagonizadas por Eduardo das Neves trazem ainda à tona uma especial politização das relações raciais nos primórdios da jovem República e uma série de temáticas que se relacionam com o mundo da escravidão e com as conquistas da abolição. Para além da sua presença nas comemorações do 13 de maio de 1909 no Méier, muitos são os sinais na obra de Dudu que evidenciam a valorização da presença do negro na formação cultural brasileira, indicando que nem só de cânones literários, artísticos e musicais europeus teria vivido a chamada Belle époque republicana. No mercado editorial e cultural da capital da república não estavam disponíveis apenas visões pessimistas sobre o Brasil e os produtos da mestiçagem. ${ }^{48}$

$\mathrm{Na}$ obra de Dudu identificamos canções que valorizavam heranças africanas (como os lundus e os jongos) e conquistas dos escravos (as amorosas, a alforria e a própria liberdade). Com temas que abordavam as relações raciais e desafiavam as teorias racistas, que insistiam na inferiorização da população negra e mestiça, encontramos versos onde

46 MARZANO, Andrea. Cidade em cena: o ator Vasques, o teatro e o Rio de Janeiro (1839-1892). Rio de Janeiro: Folha Seca, 2008

47 HERCULANO, Antonio. Vem cá, mulata! Tempo, Rio de Janeiro, v.13, n.26, 2009.

48 Sobre essa perspectiva ver ABREU, Martha e DANTAS, Carolina Vianna. Música popular, folclore e nação no Brasil, 1890-1920. In: CARVALHO, José Murilo de. (org.) Nação e cidadania no Império: novos horizontes. Rio de Janeiro: Civilização Brasileira, 2007. 
são cantadas as relações amorosas com iaiás e morenas, os encantos da mulata, a faceirice do crioulo, a valorização da cor preta frente às outras e a presença do malandro, do negro mina e das espertezas do escravo velho conhecido como pai João. Enfim, conflito racial e protesto político em meio a trocas culturais intensas e possibilidades reais de inserção profissional de um músico negro no mercado editorial e indústria fonográfica.

A canção destaque desse artigo, certamente, é a Canoa virada. Embora não tenhamos a data precisa da gravação, provavelmente entre 1907 e 1912, a autoria desconhecida reforça a possibilidade de ser uma canção das ruas, marco das lutas de maio de 1888. Dudu das Neves gravou canções de autoria própria, aliás, lutou muito por isso. Mas nunca se apropriou de canções que pareciam mesmo ser de domínio público, como a Canoa virada e Pai João. Pelo contrário, parecia querer reconhecer essas canções como coletivas. Nesses casos, a Casa Edison qualificava as canções como de "autoria desconhecida".

Ao ouvirmos hoje a canção Canoa virada gravada por Eduardo das Neves é impossível conter a emoção, pois ela nos permite acesso a uma música que parece ter sido muito cantada no final do século XIX! Passada a sensação inicial, logo nos perguntamos sobre os motivos de tal gravação tanto tempo depois da abolição. Que interesses moviam o empresário Fred Figner, da Casa Edison, para realizar tal registro? Que público estaria ávido para ouvi-lo? Se considerarmos a possibilidade de a gravação ter sido realizada em 1909, no ano das comemorações pelos 21 anos da abolição, começamos a chegar ainda mais perto dos sentidos daquela mobilização que envolveu também a posse de Monteiro Lopes.

Os problemas são grandes para os que iniciam a pesquisa com a indústria fonográfica no Brasil, especialmente nos primeiros tempos, quando não temos registros precisos sobre o ano das gravações. Mas é difícil negar a participação de Eduardo das Neves na escolha desse repertório. Eduardo era um especialista em lundus, gênero pouco conhecido pelos ouvintes de hoje, mas de grande divulgação e vendagem no período, tanto na indústria fonográfica nascente quanto nas edições musicais impressas. ${ }^{49}$ Complementarmente, gravou lundus que faziam referencia ao mundo da escravidão e das lutas pela liberdade. A presença da "Canoa Virada" no repertório de Dudu não pode ser vista de uma forma ingênua.

49 LEME, Monica. E saíram à luz: as novas coleções de polcas, modinhas, lundus etc. Música popular e impressão musical no Rio de Janeiro. Niterói: UFF, 2006. (História, Tese de Doutorado). Mesmo que possamos levantar a hipótese de Dudu ser um tipo de blackface brasileiro, personagem que presumidamente representava os negros com músicas e quadros especiais para o riso das platéias, ele era um black blakface, como muitos artistas negros nos Estados Unidos no mesmo período. Nesta condição, se suas representações musicais poderiam parecer mais autênticas, ganhavam sentidos críticos novos e bem mais profundos. A atuação de Dudu ampliava também a presença dos negros no mundo cultural e musical. O fato de ter sido contratado pela Casa Edison, que mantinha estreito contato com gravadoras nos Estados Unidos, pode reforçar os elos de Dudu com os black blackfaces naquele país. Nesta perspectiva, ver CHUDE-SOKEI, Louis. The last 'danky', Bert Williams, black-on-black minstrelsy. Durham and London: Duke Univesity Press, 2006. 
A Canoa virada é um belo lundu! E hoje pode ser ouvida, através das gravações mecânicas, com as marcas evidentes da contrametricidade da chamada música afro-brasileira. ${ }^{50}$ Mesmo que, infelizmente, nem todas as frases sejam claras e compreensíveis, apesar da voz imponente de Dudu, é através delas que podemos ter acesso a um raro documento. Muito diferente dos discursos oficiais, das poesias imponentes e românticas, como o poema Lucia, a escrava, e das missas solenes que marcavam as comemorações, a Canoa virada nos permite conhecer outras formas de comemoração: o som e o vocabulário das ruas na época da abolição. Mais ainda, pode ser vista como uma versão, musical e popular, da própria abolição. Dudu tornase com essa gravação um pouco historiador, já que registrou em versos e música o dia da abolição. ${ }^{51}$

As palavras e expressões utilizadas são fortes e desconcertantes: havia chegado "a ocasião da negrada bumbar". A canção refere-se ao 13 de maio, "o dia da liberdade", como um grande momento, de reais mudanças e de sonhos de liberdade. A "negrada" tinha motivos para bumbar. A escravidão parece estar representada por uma frágil embarcação, uma canoa, que, literalmente, havia virado. Complementarmente, é possível entender que o longo percurso da escravidão no Brasil havia se encerrado, a Canoa havia Virado. Entre ironias e sátiras com crioulas altivas, que não mais comeriam angu com feijão, e pretos sem senhores, típicas dos lundus, havia chegado "o dia da liberdade"; não havia mais razão para "baiano chorar". Todos, em vários locais, tinham desejado - e conquistado - o "dia da liberdade". 52

A partir da voz de Dudu, que ainda deixou registrado uma marca de sua interpretação no meio da canção, se chamando de "nego bom pra danado", conseguimos transcrever as seguintes frases:

\author{
A viola já deu baixa \\ Violão não tem valia (2x) \\ Até o 13 de maio meu bem... \\ A canoa revirando \\ Toda noite agüentou \\ Quando foi de madrugada \\ Foi-se embora, me deixou
}

50 SANDRONI, Carlos. Feitiço decente. Transformações do samba no Rio de Janeiro (1917-1933). Rio de Janeiro: Jorge Zahar Editor/Editora da UFRJ, 2001, caps. 1 e 2. Ver também ULHOA, Martha Tupinambá. Isto é bom! Ou Yayá, você quer morrer? A tradição oral e a tradição escrita do lundu. In: Anais do XIV Congresso da ANPPOM. Porto Alegre: Ago. 2003.

51 Para ouvir a canção, consultar o site do Instituto Moreira Sales (http://acervo.ims.uol.com.br/), Canoa Virada, Eduardo das Neves, Gravação Odeon, álbum 108739. O IMS detém o acervo da Casa Edison. Uma primeira análise dessa letra foi desenvolvida em ABREU, Martha e MARZANO, Andrea B. Entre palcos e músicas: caminhos de cidadania no início da República. In: CARVALHO, José Murilo de e NEVES, Lucia M. P. (orgs.) Repensando o Brasil dos Oitocentos: cidadania, política e liberdade. Rio de Janeiro: Civilização Brasileira, 2009.

52 Um agradecimento especial a Eduardo Silva por seus comentários sobre esse lundu. Não conseguimos, entretanto, chegar a um acordo sobre os significados do primeiro verso. 
As crioulas que só comiam

O puro angu com feijão (2x)

Agora comem tainha,

apertam o nariz então

A canoa virô

Deixá-la virá

De boca para baixo

Cacunda pro ar

Chegou ocasião da negrada bumbar

(Fala: meu Deus! nego bom pra danado)

Subi no alto do monte

Fui ver o tempo passar (2x)

E a crioula do lado, meu bem...

A canoa virô...

A viola já deu baixa

Violão não tem valor

O preto já é livre

Já que não tem senhor

A canoa virô...

Acabô ocasião pro baiano chorar

Depois de vilas e cidades

Andei pelos arrebaldes (2x)

Não há quem não desejasse, (oderê?)

O dia da liberdade

A canoa virô...

Muitos anos depois, na década de 1950, pelo que indica o trabalho do folclorista Rossini Tavares de Lima, versos muito próximos aos que eram cantados por Dudu ainda podiam ser ouvidos em São Paulo. ${ }^{53}$ Nas versões de Dudu e de Rossini, que também não especifica o informante, estavam presentes o estribilho da "canoa virô" e da alegria da "negrada", assim como os versos das faceirices "das negrinhas", chamadas por Dudu de "crioulas"uma denominação coerente com a identidade que procurava divulgar em sua obra. No registro do folclorista Rossini, a idéia de liberdade foi expressa pelo fim do "capitão do mato", que o "diabo levou". Na letra do "crioulo Dudu", porém, a linguagem era ainda mais politizada, se considerarmos a época da gravação: "o preto já era livre, porque não tinha senhor"; "não

53 LIMA, Rossini Tavares. Da conceituação do lundu. São Paulo: s/Ed., 1953, doc.14, p.23. 
havia quem não desejasse o dia da liberdade"... Na sua poesia cantada, a "negrada não só arregalava", "bumbava!".

Sem fazer referência a Eduardo das Neves, o folclorista Tavares de Lima demonstrou que em São Paulo, uma das áreas centrais da cafeicultura, do trabalho escravo e das fugas em massa que precipitaram a votação de 13 de maio de $1888,{ }^{54}$ a abolição havia sido comemorada também com a Canoa virada. Mesmo que possamos ter uma hipótese inversa a essa - os libertos de São Paulo aprenderam a canção com a música de Dudu - é possível confirmar a ampla circulação das festas pelo fim da escravidão através da música e dos versos comemorando a liberdade. ${ }^{55}$ Se quase cinquenta anos afastam os dois registros, a continuidade desta forma de expressão e comunicação parece indicar a produção de uma versão musical politizada do dia 13 de maio que não era para ser esquecida.

Através da música, poesia e festa, o "dia da liberdade" seria lembrado e festejado pelos descendentes de escravos, em diferentes locais do sudeste do Brasil. A memória da escravidão e da abolição, complementarmente, não era esquecida e ainda parecia justificar os encontros festivos. Eduardo das Neves ao gravar uma canção que, exatamente por ser de autoria desconhecida, devia estar nas ruas e nas velhas fazendas de café, faria a sua parte como poeta e músico negro. ${ }^{56} \mathrm{~A}$ música popular, especialmente os lundus, como uma cultura política, foi um canal de expressão e de comunicação para muitos segmentos da população. O mundo da política transbordava nas canções populares. ${ }^{57}$

A perspectiva de se considerar a música como canal de ação política, ou uma forma de se experimentar a política e discutir os direitos dos descendentes de africanos no Brasil, é visível nos versos e lundus de Dudu das Neves. A dimensão política da música para os descendentes de escravos tem sido trabalhada pelos estudiosos da música no Atlântico Negro e pode reforçar nosso argumento. De uma forma próxima ao que já foi realizado para os estudos sobre família escrava e visões da liberdade, as músicas e poesias, com ironias, sátiras ou lamentos, também foram fundamentais para

54 Ver MACHADO, Maria Helena P. T. Teremos Grandes Desastres, se não houver Providências Enérgicas e Imediatas": a Rebeldia dos Escravos e a Abolição da Escravidão. In: GRINBERG, Keila e SALLES, Ricardo. (orgs.) Brasil imperial, 1870-1899. Rio de Janeiro: Civilização Brasileira, 2009, v.3; SILVA, Eduardo. Domingo, dia 13: 0 underground abolicionista, a tecnologia de ponta e a conquista da liberdade. In: ABREU, Martha e SERVA, Matheus P. (orgs) Caminhos da liberdade: histórias da abolição e do pós-abolição no Brasil. Niterói: PPG.HISTÓRIA/UFF, 2011.(no prelo).

55 As comemorações do 13 de maio, de 1888 até os dias de hoje, também são registradas em encontros de jongo em diversas comunidades de descendentes de escravos. Ver ABREU, Martha e MATTOS, Hebe. Jongo, registros de uma história. In: LARA, Silvia H. e PACHECO, G. Memória do Jongo. As gravações históricas de Stanley Stein. Rio de Janeiro: Folha Seca/Cecult, 2007.

56 ABREU, Martha e MATTOS, Hebe. Jongo, registros de uma História.

57 O conceito de cultura política, neste sentido, pode auxiliar a compreender os combates políticos cotidianos, as aspirações políticas de determinados grupos e as normas, crenças e valores partilhados. Uma cultura política irrigaria um grupo humano com canais de expressão. Sobre cultura política, ver BERSTEIN, Serge. La culture politique. In: RIOUX, Jean-Pierre e SIRINELLI, Jean François. (orgs.) Pour une histoire culturelle. Paris: ditions du Seuil, 1997. 
a luta contra a opressão e dominação racial, ao longo da escravidão e no período pós-abolição. ${ }^{58} \mathrm{~A}$ Canoa virada, entre muitos outros lundus, é um ótimo exemplo de como através da música, de versos irônicos e atrevidos pode-se falar de política e de memórias que não se quer esquecer. Como afirmou Paul Gilroy, a música foi um elemento fundamental da cultura política negra desde o período escravista, quando foi negado aos escravos o direito à alfabetização, tornando-se um importante meio de representação identitária e política dos escravos e seus descendentes. ${ }^{59}$

\section{Considerações finais}

Sabemos que há um consenso, hoje questionável, entre os especialistas no estudo das relações raciais de que a integração de intelectuais negros na sociedade brasileira durante a Primeira República se deu, primordialmente, através do processo de branqueamento. Entretanto, conforme Antonio Sérgio Guimarães alertou, ${ }^{60}$ tal afirmação não deve ser compreendida como um processo de simples (ou total) reprodução da cultura e da moral do "mundo dos brancos". Naquele momento, os esforços de Monteiro Lopes e Eduardo das Neves por integração Ihes garantiram reconhecimento público, pequeno conforto material, espaços de expressão, participação e crítica política, que não podem ser minimizados. Por outro lado, também se pode argumentar que ambos podem ter tido um público - eleitores, no caso de Monteiro Lopes, e ouvintes, no caso de Dudu - minimamente variado, não só formado por negros, homens de cor e descendentes de escravos e africanos.

Os dois afirmavam-se positivamente e publicamente como negros na Primeira Republica. E, em espaços tão importantes como a música e a política, se empenharam em introduzir valores não-brancos no que se estava construindo como a nação republicana naquele período. Ao lado de outros "homens de cor" não abriram mão do sonho de ver negros e mestiços tratados, de fato, como iguais em seu país.

Em suas utopias, André Rebouças imaginava um Brasil no qual tivessem lugar todos os brasileiros, independentemente da raça ou da cor: "brancos, mulatos, negros, todos iguais, todos irmãos" ${ }^{61}$ José Patrocínio acreditava

58 Ver, por exemplo, ABRAHAMS, Roger. Singing the master. The emergence of African-american culture in the plantation south. London/New York: Penguin Books, 1992; CAPONI, Gena Dagel. The case for an African American Aesthetic In: CAPONI, Gena Dagel. (ed.) A reader in African American expressive culture. Massachusetts: The University of Massachusetts Press, 1999.

59 GILROY, Paul. Atlântico negro, modernidade e dupla consciência. Rio de Janeiro: UCAM/Editora 34, 2001, p.189 e 245. Ver também, RADANO, Ronald. Lying up a nation. Race and Black music. Chicago e London: The University of Chicago Press, 2003.

60 Ver GUIMARÃES, Antonio Sérgio A. Intelectuais negros e formas de integração nacional. Estudos Avançados, São Paulo, v.18, n.50, 2004

61 Citado por SPITZER, Leo. Os dois mundos de André Rebouças, Cornelius May e Stephan Zweig. Estudos afroasiáticos, n.3, 1980. 
que a colonização portuguesa, ao invés de aniquilar as "raças selvagens", assimilou-as "preparando-nos assim para resistir à invasão assoladora do preconceito de raças". ${ }^{62} \mathrm{E}$, por fim, nunca é demais lembrar a insistência do professor Hemetério dos Santos em afirmar o seu país como uma "construção de amor e tolerância", na qual os negros teriam papel fundamental. ${ }^{63}$ A bandeira da integração fez parte da ação política e da ação cultural de muitos artistas, lideranças e entidades negras, aparecendo também em jornais da imprensa negra paulista e na bem sucedida peça Tudo Preto, da Companhia Negra de Revista nos anos de 1920, protagonizada por De Chocolat e Pixinguinha. ${ }^{64}$

Assim, podemos considerar que Monteiro Lopes e Eduardo das Neves são exemplos notórios da participação dos negros na Primeira República, em ações políticas e culturais. Ao lado de outros indivíduos e coletividades, interferiram na história e ampliaram as possibilidades da cidadania e de inclusão na jovem república, mesmo que os ganhos sociais e políticos resultantes dessas práticas de expressão e participação tenham sido formalmente restritos. Também tentaram fazer com que suas ações, discursos, textos e canções não fossem esquecidos. Logo, a ideia de que a então jovem república não assegurou uma cidadania plena para a população negra não pode ser confundida com os espaços políticos e direitos pelos quais a população negra - ou parte dela - lutou, a despeito do que lhes tentaram negar ou impor. Apesar de todas as restrições, negros como Lopes e crioulos como Dudu fizeram política e ampliaram a experiência de cidadania na Primeira República. Cabe aos historiadores de hoje a reconstrução dessas experiências e de muitas outras histórias.

62 PATROCÍNIO, José do. O grande projeto. In: Gazeta da tarde. 05/05/1887.

63 SANTOS, Hemetério dos. Machado de Assis. Almanaque Brasileiro Garnier, 1910, p.369-374.

64 GOMES, Tiago de Melo. Afro-brasileiros e a Construção da idéia de democracia racial nos anos 20. Revista Linhas, v.8, n.1, 2007; BARROS, Orlando. Corações de chocolat. A história da Companhia negra de revistas (19261927). Rio de Janeiro: Livre Expressão, 2005. GUIMARÃES, Antonio Sérgio A. Notas sobre raça, cultura e identidade negra na imprensa negra de São Paulo e Rio de Janeiro, 1925-1950. Afro-Asia, v.29/30, 2003; GUIMARÃES, Antonio Sérgio A. Democracia racial. Cadernos Penesb, Niterói, n.4, 2002. 